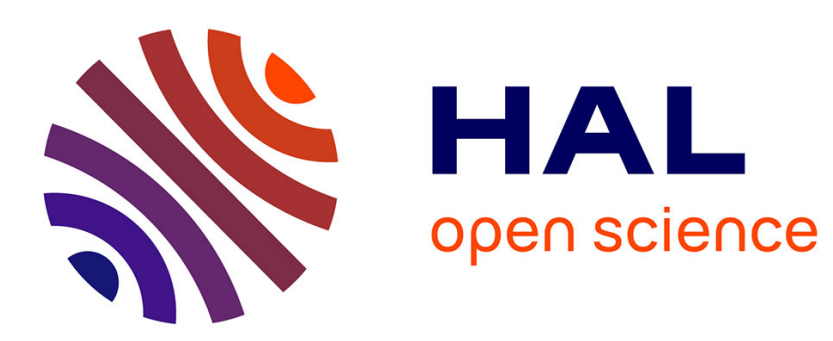

\title{
New instruments in innovation policy: The case of the Department of Trade and Industry in the UK
}

\author{
Isabel Maria Bodas Freitas
}

\section{To cite this version:}

Isabel Maria Bodas Freitas. New instruments in innovation policy: The case of the Department of Trade and Industry in the UK. Science and public policy, 2007, 34 (9), pp.644-656. 10.3152/030234207x264935 . hal-01487503

\section{HAL Id: hal-01487503 \\ http://hal.grenoble-em.com/hal-01487503}

Submitted on 12 Mar 2017

HAL is a multi-disciplinary open access archive for the deposit and dissemination of scientific research documents, whether they are published or not. The documents may come from teaching and research institutions in France or abroad, or from public or private research centers.
L'archive ouverte pluridisciplinaire HAL, est destinée au dépôt et à la diffusion de documents scientifiques de niveau recherche, publiés ou non, émanant des établissements d'enseignement et de recherche français ou étrangers, des laboratoires publics ou privés. 
Cite as: "Bodas Freitas, I.M., (2007). New instruments in innovation policy: The case of the Department of Trade and Industry in the UK. Science and Public Policy, 34 (9), 644-656."

\title{
New instruments in innovation policy: The case of the Department of Trade and Industry in the UK
}

\author{
Isabel Maria Bodas Freitas
}

\begin{abstract}
This paper studies how investments in knowledge codification may be used as innovation policy tools, in a non-interventionist policy environment. Analysing statistically and historically the case of the UK's Department of Trade and Industry, from the early 1980s to 2002, the paper shows how knowledge codification can be used as policy-instrument for restructuring the design, characteristics and implementation of public innovation support as well as for developing new national competitive competences. This paper suggests that within a context of outsourced policy implementation and execution, the continuous upgrade of public support for innovation requires that both governmental department and external suppliers engage in 'learning-by-codifying'.
\end{abstract}

Key words: Knowledge codification, continuous improvement, innovation policy, standards, benchmarking, innovation policy instruments

The author would like to acknowledge the comments and suggestions of two anonymous referees, Bart Verspagen, Alessandro Nuvolari and Roberto Fontana, usual disclaimer applies. 
Isabel Maria Bodas Freitas is currently post-doc researcher at Technology and Policy Unit, Technology Management Faculty, Eindhoven University of Technology. She received her $\mathrm{PhD}$ in Science and Technology Policy Studies at SPRU, University of Sussex, in 2006. Her research areas include innovation policy, development and diffusion of innovations, organisational and managerial innovations, and university-industry links.

\section{Introduction}

From the early 1980s onwards, OECD countries have been engaging in changing their public sector management, towards a more performance-based culture and less governmental direct intervention in the market (OECD, 1993). Moreover, new understandings of the sources of national competitiveness and of the role of industrial and science policies were emerging. In particular, innovation diffusion across small and medium enterprises, local and regional entrepreneurship and policy initiatives became increasingly understood as crucial for national competitiveness (Chabbal, 1995; Andersson, 1998; Metcalfe and Georghiou, 1998). Hence, industrial and science policies became increasingly concerned with innovation, and public business support became more immaterial, pervasive, and more carried out through networks (Andersson, 1998; Sharp, 2000; Mytelka and Smith, 2002; OECD, 2004). Thus, the development and diffusion of innovations and best-practices (i.e. practices recognised as effective for dealing with organisational, managerial, social and technical challenges required to build a certain dynamic capability (Eisenhardt and Martin, 2000)) became the central objective of industrial and science policies.

Against these developments, the academic literature, both in management and economics, engaged in a great debate on the impact of knowledge codification (i.e. process by which knowledge is partly transformed into information), and consequently on the role of codified knowledge (i.e. result from knowledge codification processes, such as models, manuals, 
languages, standards, best-practices) on the process of innovation development and diffusion (Cowan and Foray, 1997; Cohendet and Steinmueller, 2000). This debate became of special relevance for organisations which outsource part of their production and learning activities to their suppliers, since the continuous improvement of their products relies on the upgrading the capabilities of their several distant suppliers (Argote and Darr, 2000; Bessède, 2000; Kimberly and Hollingworth, 2004).

Similarly, innovation policy-makers need to improve continuously the design, content/characteristics and implementation of public support in order to accomplish their objective of supporting national firms to develop promptly new competences and maintain competitive in the global learning-economy. Thus, the understanding of how knowledge codification and codified knowledge may be used as innovation policy instruments is then of crucial importance for most OECD governments, especially when policy implementation has been outsourced.

This paper studies how the development and distribution of codes and standards may be used as policy instruments to monitor and upgrade innovation policy, in an apparently noninterventionist policy environment, which is against the use of direct financial incentives to firms and favours the outsourcing of policy execution. The analysis is carried out empirically by relying on historical evidence as well as on data on public support for innovation and on investments in knowledge codification undertaken by the Department of Trade and Industry (DTI) from 1980 to 2002, whose mission is supporting the productivity and performance of UK firms.

\section{Knowledge codification, innovation and diffusion}

In this section, we review the management and economics literature on the role of knowledge codification and codified knowledge for innovation development, as well as more specifically for organisations that outsourced part of their production, marketing and learning activities to 
a network of suppliers. Moreover, we analyse their potential uses for adaptive innovation policy.

\subsection{Knowledge codification and innovation development in firms}

The debate on the impact of knowledge codification on the innovation process is wide and extensive. Some authors argue that efforts to convert knowledge into transferable information leads to knowledge crystallisation, to organisational inertia and strengths internal rigidities (Cowan and Foray, 1997; Cowan et al., 2000). Other authors, instead, argue that knowledge codification is essential to appropriate and transform knowledge and skills of employees into new products and organisational practices and to enhance innovation (Cohendet and Steinmueller, 2000; Coriat and Dosi, 2002).

This debate revolves mainly around the role played by external codified knowledge (i.e. results from knowledge codification, such as models, manuals, languages, standards, bestpractices). On the one hand, the development and diffusion of codified knowledge makes easer to reproduce knowledge under different contexts and to expand the existing understanding of managerial, organisational and technological practices (Cohendet and Steinmueller, 2000; Coriat and Dosi, 2002; Bénézech et al., 2001). Indeed, as Foray and Steinmueller (2003: 314) suggest, external codified knowledge are tools "to screen and classify information and to open new opportunities for modelling knowledge and to learn". The use of these tools enables organisations to understand how information needs to circulate and where learning takes place, to observe and articulate individual knowledge and to evaluate their organisational structures and practices as well as their position in the market (Cowan and Foray, 1997; Cohendet and Steinmueller, 2000; Bénézech et al., 2001). Hence, adoption of external codified knowledge may also help organisations to engage in organisational learning towards the implementation of some well-tested practices and technologies to improve certain business processes (Coriat and Dosi, 2002; Bénézech et al., 2001). Thus, adoption of external codified knowledge may facilitate the development of new 
knowledge through the combination and integration of external knowledge and internal learning experience into new capabilities, products and organisational structures.

On the other hand, despite providing a framework to codify and learn, the use of external codified knowledge may limit the capability of organisations to develop radical new knowledge because they encourage learning on specific pre-existing frameworks (Cowan and Foray, 1997; Cowan et al., 2000). Moreover, the use of external codified knowledge tends to raise issues of interpretation as well as of adaptation to specific technical and organisational contexts. Indeed, to learn from codified knowledge, organisations need to interpret, combine and use it in the light of the internal organisational and technical specificities (Cohendet, 2001; Cohendet and Meyer-Krahmer, 2001). Opportunities for improvement from the adoption of codified knowledge only emerge if organisations learn the code and if the new specific knowledge, created through learning the code, is transformed (i.e. codified) into new organisational practices and products (Bénézech et al., 2001). Hence, organisations must have an 'absorptive capacity' to access and use the potential knowledge of these codes and standards for enhancing their technological and organisational effectiveness (Cohen and Levinthal, 1990; Dosi et al., 2000; Coriat and Dosi, 2002; Foray and Steinmueller, 2003). Consequently, codified knowledge is not an accumulated stock of information, independent of the capabilities and environment of its users (Cohendet, 2001).

In short, knowledge codification seems to be the basic process allowing organisations to absorb external knowledge as well as the knowledge held and generated by their workers into new practices and products. Because, to benefit from knowledge developed through learningby-doing, -using and -interacting, organisations need to transform it into new information, strategies, routines, and products. However, procedures favouring knowledge codification and the use of codified knowledge may enhance and eventually accelerate response to changing environments, but not the development of radical novel organisational and technological knowledge. Because, these procedures encourage learning processes based on pre-existing 
explicit knowledge codes and frameworks. Moreover, the impact of external codes on organisations depends on their capabilities to use and transform the knowledge that it represents to renew their capabilities and practices. Codifying capabilities, which are related to the technical, organisational and managerial knowledge of organisations, seem to define (together with these other capabilities) the ability to absorb external codified knowledge or to proceed to innovate. This may be even more relevant for organisations that outsource part of their production and that co-ordinate a network of suppliers.

\subsection{Knowledge codification and the co-ordination of a network of suppliers}

Since knowledge codification might be strategically used to embody internal and external knowledge into new practices and products, explicit investment in knowledge codification and distribution may be of great importance for the main-contractor (i.e. the coordinator of a network of suppliers organisations) to maintain innovative and competitive advantage of their products. Cohendet (2001) identifies two strategies for which knowledge codification can be used to deal with problems related to outsourcing and co-ordination of distant suppliers. The 'vertical codification strategy' attempts to codify and take over knowledge held by other organisations. The 'horizontal codification strategy' supports diffusion of new best-practices across internal divisions or external organisations within a network by codifying knowledge in a way that can be interpreted and used almost without restriction.

On one hand, under imperfect information, monitoring is costly and difficult to achieve. Consequently, organisations relying on networks of suppliers try to induce a desired performance from their suppliers by requiring them to meet certain procedures and standards (Bessède, 2000; Kimberly and Hollingworth, 2004). The adoption of codes and standards may help their users to learn new technical or managerial best-practices in the context of their internal specificities (Bénézech et al., 2001). Argote and Darr (2000) showed how knowledge, once codified, could be transferred across subsidiaries of firms but not across competitors; while, most of innovations not stored into routines or codes could not be transferred out of 
their site of origin. Therefore, by investing in the development and posterior diffusion of bestpractices, the main-contractor may lower the costs and risks of coordinating production and its quality, communication and innovation across a network of distant suppliers.

These investments may also facilitate the integration of both internal and outsourced activities, since the process of knowledge codification, in which suppliers engage through adoption of codes and standards, may produce information for the main-contractor on the work and learning routines of their suppliers (Bénézech et al., 2001; Cohendet, 2001). In particular, Cohendet (2001) argues that ISO certification processes as a requirement to supply large multinational firms may be seen as an effort to absorb and control knowledge of small suppliers. Indeed, the fact that suppliers codify their knowledge into work specifications may allow the main-contractor to better plan and coordinate the production activities of internal divisions and of its specialised-suppliers. Moreover, by requiring suppliers to adopt specific standards and procedures, and consequently to codify their knowledge into specific work practices, main-contractors may introduce more easily and quickly a new supply specification across their suppliers. This is not only because main-contractors may give more specific instructions on how to accomplish this new requirement, but also because suppliers, who are more capable of codifying, might also more easily identify what they need to change to be able to meet the new delivery requirements.

On the other hand, the process of learning and innovating by using codified knowledge is not automatic. As seen in Section 2.1, organisations need to learn external codes in the light of their organisational and technical specificities and to transform that learning into new practices, products and capabilities. Hence, the improvement of products and capabilities within an organisation, which outsources parts of its production and learning activities, depends on the upgrade of technical and codifying capabilities of its suppliers and consequently on the effective use of codified and distributed knowledge. Thus, both the maincontractor and its suppliers need to be able to engage in 'learning-by-codifying' (i.e. learning 
to use efficiently codified knowledge to develop new internal knowledge and to codify their knowledge into new capabilities, practices and products). Hence, the quick diffusion of bestpractices and renewal of capabilities across a network of suppliers seems greatly dependent on the efforts put on the development of codifying and technical capabilities of firms.

\section{Knowledge codification and adaptive innovation policy}

To support national firms to develop new competences and maintain competitive in the global learning-economy, innovation policy is increasingly requested to be adaptive. Consequently, policy-makers are increasingly required to learn and innovate policy objectives and strategies (Paasi, 2005, 19-20). In particular, policy-makers need to improve continuously the implementation performance of innovation policies, as well as to update policy objectives, and the characteristics and message of public support, as the competitive challenges faced by national firms evolve (Callon et al., 1991; Lipsey and Carlaw, 1997).

Representing a structured approach to learning through analyses and comparison of existing policy practice and experience, benchmarking is considered an instrument for adaptive policy. It allows assessing the current performance of policy activities and implementation practices, as well as collecting information on best-practices cases, which may permit the definition of better performing policies and practices (Paasi, 2005). Benchmarking can be undertaken at national or at international level, individually or collectively by different policy parts.

In particular, in the context of the public sector reform, benchmarking exercises - either bottom-up or top-down, depending on whether is the government or local organisations who decide the criteria, standard and targets of the exercise- , as well as public procurement and standard setting may be of great importance for raising the performance of local public organisations (Papaioannou et al., 2006; Edler and Georghiou, 2007). Moreover, investments in compilation of best-practice case studies may support local organisations, delivering public services, to internalise external knowledge into targets and milestones (Kinder, 2002). 
Noteworthy is the fact that codified packs of knowledge are both inputs (criteria for comparison and measurement, targets) and the outputs (best-practices, standards, code of conduct, scoreboards) of these exercises. Hence, issues of interpretation, assessment, validity and potential impact for improving innovation policy also affect these activities. Indeed, as the use of benchmarking multiplies, several studies discuss its real effectiveness. In particular, the validity of this exercise and its outputs depends on the quality of the set criteria and on the way these criteria are measured (Papaioannou et al., 2006). Hence, benchmarking is increasingly recommended not as a policy-solution, but as a methodology to learn and collect information on policy practices and performance (Paasi, 2005).

Moreover, to take actively the lead on the development of new national competences, policymakers are also recommended to invest in procurement of the demand and supply for innovations (Edler and Georghiou, 2007). Thus, more than continuously adapting the provision of financial incentives and services supporting innovation in firms, policy-makers need to keep investing in regulation, standards setting, development of lead markets, and in specific R\&D procurement (Edler and Georghiou, 2007). These policies are again based on processes of knowledge codification.

Summing up, several policy-learning exercises, based heavily on knowledge codification, have been recommended and used for supporting innovation development and diffusion. Still, a systematic study of how investments in the codification of knowledge held by managers, consultants, business experts and policy-providers, as well as in the distribution of these codes were used as innovation policy instruments has not been done yet. This paper is an attempt to do so by focusing on the innovation policy carried out by the DTI in UK, between the early 1980s and 2002.

\section{Background information on the DTI and historical context}


An understanding of the DTI activities cannot be disjoint from the context in which the policies were carried out. This section briefly reviews the historical process by which the DTI increasingly focused on the provision of more immaterial and wide-accessible public support for innovation as well as on the outsourcing of policy implementation to a network of private policy-providers.

In 1979, the Conservatives came to power, committed to refrain from intervening directly in the economy. The financial constraints of the 1970s and 1980s, which included awareness of the size and cost of public sector and public deficits, forced the introduction of new attitudes concerning the role of the government and public sector as a problem-solver and serviceprovider (Marsh and Rhodes, 1992; Parsons, 1995; Sharp, 2000). Hence, from the early 1980s, the DTI has been confronted with the need both to assure its mission to improve UK business performance while conforming to an increasingly non-interventionist political environment. Following the second oil shock, British manufacturing production continued to decline 'Made in Britain' was no longer a sufficient assurance of product quality, and there was a lack of management skills (DTI, 1986, 1989). Within this context of weak support for national non-price competitiveness, support for innovation quickly became a central issue (Sharp, 2000). However, the preference for hands-off management, competition, privatisation and cost cutting greatly restricted the available instruments for industrial policy (Marsh and Rhodes, 1992; Parsons, 1995; Sharp, 2000). Consequently, from 1980 onwards neo-liberal British industrial policies increasingly aimed at supporting firms to engage in better-informed decision-making by diffusing information on best-practices and providing consultancy advice (Sharp, 2000).

Additionally, a reform of the British public sector diffused the philosophy that "value for money" can be best achieved by a separation of roles between those who set the policy and those who deliver it (OECD, 1993; Parsons, 1995; Downing, 2001). In particular, from 1987 
onwards, most of the public business support initiatives for innovation, which were centralised in the DTI head office, such as business and technical advisory services (BTAS) and some diffusion campaigns, were put together under Enterprise Initiatives (EI) delivered locally by the recently created DTI Regional Offices. These initiatives run in parallel to advice services provided by Small Firms Service, Enterprise agencies, and chambers of commerce. From 1988, with the publication of the white paper 'Improving Management in the Government: The Next Steps', which recommended the creation of agencies to carry out the executive functions of government within a policy and resources framework approved by the minister responsible, the DTI has been further encouraged to outsource policy execution. The Next Step Initiative aimed at taking a step towards a clearer functional division between policy-making and policy execution and resulted in greater scope for private sector provision (DTI, 1986; OECD, 1993). To better achieve this purpose, the DTI launched a call for local partnerships, the Business Links, to establish a nationwide network of 'one-stop shops' and to bring together various sources of DTI business support (DTI, 1995a, 1995b). Thus, from 1995 , most of the direct public business support is delivered by local private organisations, mainly the Business Links. In 1999, the creation of the DTI Small Business Service, as next step agency, started to be planned with a specific target of improving co-ordination of local and regional policy organisations, especially between Business Links and Regional Development Agencies (DTI, 1999a).

Given this political and economic context, the DTI found itself facing the needs to support national firms to innovate while keeping track of the several new and emerging best-practices while, at the same time co-ordinating a great variety of assistance services provided by a network of policy-providers. As a consequence, the DTI became increasingly the identifier of the wide policy-making objectives and the co-ordinator of policy implementation, while the local policy actors were the producers and suppliers of public support to firms, which 
continue to be the final 'customers' for innovation policy. A policy 'learning organisation', the DTI, became the coordinator of a network of suppliers of business-to-business services.

\section{Methodology and Data}

To study the role of investments in the development and distribution of codified knowledge as innovation policy instruments, we focus on information on policy programmes, launched by the DTI between 1980 and 2002. In particular, we consider policy programmes that provided direct assistance to management and innovation in firms as well as investment in the improvement of policy and knowledge infrastructures available to support firms' innovative activities. Policy programmes/schemes are here understood as organisations or projects, which coordinate and reward individual and collective learning for a determined period of time in order to accomplish specific objectives.

Information on 81 British policy programmes was collected from the government expenditure plans of the DTI, and was complemented with information obtained from programme evaluation reports, promotional leaflets, DTI-related web pages and archives of The Financial Times and The Economist. ${ }^{\mathrm{i}}$ To construct the database, policy programmes were characterised according to several design details:

- Period in which they were launched: 1983-87, 1988-94, 1995-1998, 1999-2003;

- Nature of incentives provided (i.e. actors addressed, type of support provided to firms;

- Activities and capabilities supported and degree of customisation of public support;

- Structure of policy implementation (i.e. organisation of implementation, the role of central departments, responsibilities for policy delivery and evaluation procedures);

- Main policy objectives.

Most variables were built as dichotomous variables and few as categorical and ordinal. 
Moreover, for each programme, information on knowledge codification and on the use of codified knowledge was captured into four dummy variables. Two variables assess the use of codified knowledge and the other two identify investments in knowledge codification. Information on whether the programme used codified pack of knowledge, such as standards, benchmarking tools, guides, studies or other best-practices codes to address and support firms in the upgrading of their capabilities was included in the variable 'Standards and codes to address firms'. Information on whether policy programme required policy-providers to use and conform with codified packs of knowledge, such as professional or services standards and codes of best-practices, was captured by the variable 'Requirement to conform to standards'.

The variable 'Codification of management knowledge' indicates if a programme includes efforts on codification of management best-practices into different informational and guiding codes. In particular, if the programme involves efforts to address management professionals and experts to develop new benchmarking tools, guides, knowledge on the adoption and impact of best-practices. The variable 'Codification of policy knowledge' instead indicates if a programme includes activities of knowledge codification related to the characteristics/content or the implementation of public support for innovation. In particular, if programme encourages policy-providers to codify their knowledge on the firms' needs in proposals/effective development of new services as well as to identify best-practices on the provision of innovation support to firms.

Figure 1 summarises the evolution from early 1980s to 2002 of the share of investments in codification, use of codified devices, and policy programmes implementation. Shares were calculated on the basis of a count of all programmes. The figure shows that investments in knowledge codification in the DTI policy programmes increased after the publication of The Next Step Initiative, in 1988. This coincides with the decentralisation of policy implementation to the DTI regional offices and to the early planning of full outsourcing of policy implementation. From 1995 onwards, as policy implementation was outsourced to 
local private partnerships of policy-providers, the use of codified devices increased greatly. This evolution towards increased efforts on the development and distribution of codified knowledge is mostly notorious for policy than for management knowledge, as policy focus on best-practice and information diffusion across to support firms' performance remounted the early 1980s (DTI, 1986, 1989).

\section{Figure 1: Investments in knowledge codification and use of codified devices}

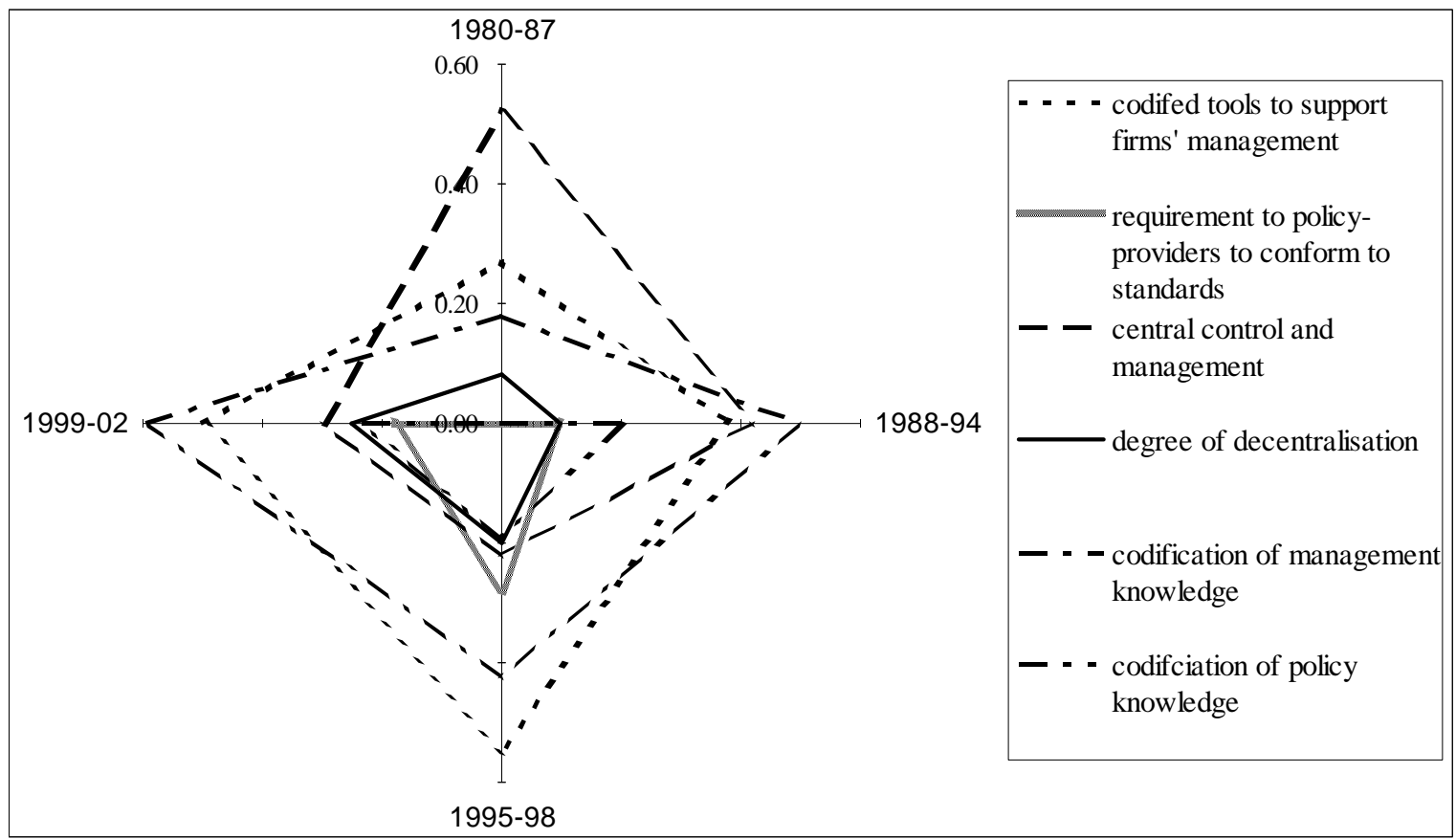

Note 1: Elaboration by the author based on several sources

Note 2: Number of programmes: 13 (period 1); 20 (period 2); 26 (period 3) and 22 (period 4).

To gain a better understanding of the policy-instrument role played by codification activities, emphasis needs to be put upon the empirical analysis of differences between programmes that include and do not include investments in codification as well as between programmes that make use of codes and those do not use them. For this purpose, non-parametric T-tests and correlation coefficients are run on our dataset of 81 programmes designed and financed by the DTI. The statistical results are analysed and interpreted in the light of the policy strategies of the DTI in the 1980s and 1990s.

\section{The policy uses of knowledge codification and codified knowledge}


In this section, we analyse empirically the uses of knowledge codification and codified knowledge as policy-instruments for innovating continuously policy design and implementation, and for encouraging directly national firms to renew their capabilities.

\subsection{Knowledge codification and the co-ordination of policy-providers}

Table 1, column 1, reports the correlation coefficients and T-test for the variable Codification of policy knowledge.

Table 1: Spearman's correlation for significant Mann-Whitney t-test differences in British programmes - grouping variable: Codification of policy knowledge and Requirement to conform to standards

\begin{tabular}{|c|c|c|c|}
\hline $\begin{array}{l}\text { Characteristics of } \\
\text { programmes }\end{array}$ & Variables & $\begin{array}{c}\text { Codification of } \\
\text { policy knowledge } \\
\text { (a) }\end{array}$ & $\begin{array}{l}\text { Requirement to } \\
\text { conform to } \\
\text { standards (b) } \\
\end{array}$ \\
\hline Time & Period & $0.253^{* * *}$ & $0.218 * *$ \\
\hline \multirow{2}{*}{$\begin{array}{l}\text { Type of support / benefit } \\
\text { for firms }\end{array}$} & Information & & $0.297 *$ \\
\hline & Services & & $0.446^{* *}$ \\
\hline \multirow{2}{*}{$\begin{array}{l}\text { Customisation of public } \\
\text { support to firms' needs }\end{array}$} & Customisation firms' needs & & $0.442 * *$ \\
\hline & Similar across country & & $-0.693 * *$ \\
\hline \multirow{5}{*}{$\begin{array}{l}\text { Organisation of } \\
\text { programme, } \\
\text { Implementation and the } \\
\text { role of central } \\
\text { departments }\end{array}$} & Central control management & $-0.267 *$ & $-0.634 * *$ \\
\hline & Other org design & & $0.394 * *$ \\
\hline & Network local org & $0.267 *$ & $0.783 * *$ \\
\hline & Level decentralisation & $0.276^{*}$ & $0.623^{* *}$ \\
\hline & Calls & $0.359^{* *}$ & $0.625 * *$ \\
\hline \multirow{2}{*}{$\begin{array}{l}\text { Form and responsibility } \\
\text { for policy delivery }\end{array}$} & Different types org & & $0.301 *$ \\
\hline & Private org & & $0.535^{* *}$ \\
\hline Evaluation procedures & Evaluation & $0.347 * *$ & \\
\hline $\begin{array}{l}\text { Macro Objectives of } \\
\text { programmes }\end{array}$ & Services improvement & $0.398^{* *}$ & $0.393 * *$ \\
\hline \multirow{3}{*}{$\begin{array}{l}\text { Knowledge codification } \\
\text { and use of codified } \\
\text { knowledge }\end{array}$} & Codification policy knowledge & & $0.463^{* *}$ \\
\hline & $\begin{array}{l}\text { Codification management } \\
\text { knowledge }\end{array}$ & & $-0.340^{*}$ \\
\hline & $\begin{array}{l}\text { Requirement to conform to } \\
\text { standards }\end{array}$ & $0.472 * *$ & \\
\hline
\end{tabular}

Note 1: * significance at the $95 \%$ level; ** significance at the $99 \%$ level (2-tailed)

Note 2: (a) 81 observations (all programmes); (b) 48 observations (only programmes providing direct support to firms)

Note 3: Correlation coefficients are only reported for variables found to be significantly different between programmes (a) that invest and those that do not invest in codification of knowledge related to 
public business support (b) that require and those that do not require policy-providers to adopt standards

Results suggest that investments in codification of knowledge related to public business support were mainly included in programmes that aimed at encouraging the creation of new business-to-business markets and at improving and monitoring the quality of public business support services provided by local private organisations (0.398). These codification investments were significantly associated with outsourced implementation of innovation support (0.267), and with requirements for policy-deliverers to conform to certain standards (0.472). They became increasingly important after the publication of The Next Steps Initiative, in 1988 and especially from 1995 when public business services was outsourced (0.253). Additionally, these codification investments were significantly associated with the issuing of open calls addressed to policy-deliverers (0.359).

In the early 1990s, the DTI encouraged the development of skills standards for the individuals providing public business support, such as the Certified Practitioner and the Professional practice of business counselling (British Accreditation Bureau, 2004; Institute of Business advisers, 2004). In the mid 1990s, the DTI codified knowledge on management, services provision and on the needs of firms into new tools such as the Benchmark index or Connect material. These codes were developed for being used by the local private policy-providers of business support (the Business Links agencies) to provide specific national branded (and relatively standard) public innovation support services to local firms (DTI, 1995a, 1995b, 1999a). Therefore, these codes allowed the development of new public business support, the customised and specialised business-to-business services (the Diagnostic Service, the Benchmarking Service) provided locally by the DTI policy-providers to help the upgrade of local firms' capabilities. 
From mid 1990s, as most of public support for innovation starts being implemented and designed by local private policy-providers, codification of policy-delivery best-practices became crucial for improving the quality and the homogeneity of local provision of both informational and specialised business-to-business services (Cassell, 1996; Campbell, 1997). The DTI invested in codification related to capabilities of providing public innovation support services. Professional standards for policy provision centres, such as 'Technology means business' or the 'Standard of Professional Competencies', were developed, in the late 1990s (Campbell, 1997; DTI, 2000, 2002; TMB, 2004). Moreover, evaluation and benchmarking of local services, sponsored by the DTI and undertaken by local policy-providers or external consultants, allowed acknowledging the specificities of public innovation support services provision and tapping the knowledge of best-performing services. These codification exercises permitted to set best-practices and quality measures in the network of policyproviders (DTI 1997a, 1998, 1999a, 2000, 2002).

Additionally, from mid 1990s, through open calls to encourage new developments in the public sponsored business-to-business market, the DTI started challenging potential policyproviders to analyse and evaluate the needs of firms in relation to the DTI's objectives, and to codify that knowledge into proposals for new services (DTI, 1997a, 1998). For example, under Information Society programme for business (later UK Online for Business), the DTI called local policy-providers (mainly Business Links) to propose and develop specialised services, as well as advice and information services on information and communication technologies and e-commerce to local firms (DTI, 1997a, 1998, 1999a, 2000, 2002). ${ }^{\text {ii }}$ Hence, the DTI started involving private local organisations in meeting its objectives by providing them with financing to customise and/or design new services to support adoption by local firms of the new best-practices identified by experts. These bidding exercises both challenged potential policy-providers to codify, and obliged the DTI to codify its own policy objectives in the text of the call. Consequently, they supported internal and external processes of 
codification of knowledge on the firms' needs and on their competitive environment into new policy objectives and public innovation support.

Given this new way of updating and launching new public business support, in the late 1990s, public support available to firms varied significantly across regions. Moreover, as local policy-providers offered both public-sponsored and full-rated services to firms, the overall visibility and quality of public innovation support was under minded (Campbell, 1997; DTI, 1999a, 2000, 2002). Aimed at homogenising public innovation assistance available to local firms across the decentralised network of policy-providers and at improving its visibility and quality, the DTI invested in codification of some characteristics of public support available to firms. In particular, in 2001, the DTI created the 'Small Business Services' as the master brand of the British public business assistance (DTI, 2000, 2002). In 2003, the DTI created and contracted to local policy-providers a new scheme 'Implement best business practice' (DTI, 2004).

Results of correlation analysis and T-test for the variable Requirement to conform to standards, in Table 1, column 2, suggest that in the second half of the 1990s, as policy implementation was being mostly outsourced, investment in policy knowledge codification the DTI required local private policy-providers to meet certain standards $(0.218)$ increased. Moreover, programmes in which the DTI requires policy-providers to adopt standards were mainly those implemented and delivered by local private organisations $(0.783)$ and those including efforts to codify policy knowledge (0.463). Therefore, the requirement for policyproviders to adopt standards was associated with the possibility of local customisation (0.442) of standardised advice and information services $(0.446,0.297)$ as well as with the outsourcing of delivery, implementation and part of the design of policies $(0.535,0.623,0.394)$ to private organisations mainly through launching of open calls (0.625). Hence, requirement to policyproviders to comply with standards was mainly related to the private and decentralised 
provision of public-sponsored innovation support, which mainly consisted of business-tobusiness services (information, advice and specialised services).

To monitor the activities of these private policy-providers, financed by the DTI or other public or European funds, the DTI replaced its controlling routines (DTI, 1998, 1999a). Direct control of programme implementation and delivery (-0.634) was replaced by asking policyproviders to adopt ISO 9000, Investor In People, and later the Technology Means Business (for organisations providing ICT and e-commerce specialised services) and the Standard of Professional Competencies (DTI, 1995a, 1995b, 1999a, 2002; Campbell, 1997; TMB, 2004). This enforcement on policy-providers was expected to facilitate monitoring and to improve quality and homogeneity (0.393) of the locally contracted public business support (i.e. information, advice and specialised services), available at sponsored prices for local firms. In this context, evaluation procedures started focusing on the assessment of the rationale, rate of penetration and level of achievement of the underlying policy objective, rather than on the particular benefits for firms that used the support, as when policy delivered was done and directly monitored by the DTI.

Investments in codification of internal knowledge of the DTI and of policy-providers aimed at the further development of policy-providers capabilities and at the upgrading the design and characteristics of existing public innovation support, which consisted mainly of local information and advice as well as specialised business-to-business services. These investments also played an important role in the reorganisation of control and monitoring of outsourced and internalised activities. In particular, requiring policy-providers to comply with certain standards went in parallel with the outsourcing of policy execution, and substituted for the DTI direct control of implementation and delivery.

\subsection{Knowledge codification and public support for innovation in firms}


Results of correlation analysis and T-test for the variable Codification of management

knowledge are reported in Table 2, column 1.

Table 2: Spearman's correlation for significant Mann-Whitney t-test differences in British programmes - grouping variable: codification of management knowledge and Standards and codes to address firms

\begin{tabular}{|c|c|c|c|}
\hline $\begin{array}{l}\text { Characteristics of } \\
\text { programmes }\end{array}$ & Variables & $\begin{array}{c}\text { Codification of } \\
\text { management } \\
\text { knowledge (a) } \\
\end{array}$ & $\begin{array}{c}\text { Standards and } \\
\text { codes to address } \\
\text { firms (b) } \\
\end{array}$ \\
\hline Time & Period & $0.253^{* *}$ & $0.170 *$ \\
\hline \multirow{3}{*}{$\begin{array}{l}\text { Type of support / benefit } \\
\text { for firms }\end{array}$} & Subsidies & $-0.308 * *$ & $-0.457 * *$ \\
\hline & Information & & $0.413 * *$ \\
\hline & Demonstration & $0.312^{* *}$ & $0.422^{* *}$ \\
\hline $\begin{array}{l}\text { Activities and } \\
\text { capabilities supported }\end{array}$ & Organisation management & & $0.325^{*}$ \\
\hline \multirow{2}{*}{$\begin{array}{l}\text { Customisation of public } \\
\text { support to firms' needs }\end{array}$} & Customisation firms' needs & $-0.409 * *$ & \\
\hline & Similar across country & $0.346^{* *}$ & \\
\hline \multirow{5}{*}{$\begin{array}{l}\text { Organisation of } \\
\text { programme } \\
\text { Implementation and the } \\
\text { role of central } \\
\text { departments }\end{array}$} & Central implementation & $-0.406 * *$ & $-0.514 * *$ \\
\hline & With experts & $0.598 * *$ & \\
\hline & Other org design & $0.409 * *$ & $0.406^{* *}$ \\
\hline & Level decentralisation & & $0.381 * *$ \\
\hline & Calls & $-0.381 * *$ & \\
\hline \multirow{3}{*}{$\begin{array}{l}\text { Form and responsibility } \\
\text { for policy delivery }\end{array}$} & Different types org & $0.274 *$ & $0.317 *$ \\
\hline & Public org & $0.323 * *$ & \\
\hline & Forms of access & & $0.449 * *$ \\
\hline Evaluation procedures & Evaluation & $-0.272 *$ & $-0.291 *$ \\
\hline \multirow{2}{*}{$\begin{array}{l}\text { Macro Objectives of } \\
\text { programmes }\end{array}$} & Best-practices Diffusion & $0.292 * *$ & $0.853 * *$ \\
\hline & Technology diffusion & & $-0.395 * *$ \\
\hline \multirow{3}{*}{$\begin{array}{l}\text { Knowledge codification } \\
\text { and use of codified } \\
\text { knowledge }\end{array}$} & $\begin{array}{l}\text { Codification management } \\
\text { knowledge }\end{array}$ & & $0.426^{* *}$ \\
\hline & Codes to address firms & $0.439^{* *}$ & \\
\hline & $\begin{array}{l}\text { Requirement to conform to } \\
\text { standards }\end{array}$ & $-0.248^{*}$ & \\
\hline
\end{tabular}

Note 1: * significance at the $95 \%$ level; ** significance at the $99 \%$ level (2-tailed)

Note 2: (a) 81 Observations (all programmes); (b) 48 observations (only programmes providing direct support to firms)

Note 3: Correlation coefficients are only reported for variables found to be significantly different between programmes (a) that invest and those that do not invest in codification of management knowledge; (b) that use and those that do not use codified packs of knowledge to support management in firms 
The positive and significant coefficients suggest that investments in codification of management knowledge were associated with the development and distribution of informational and demonstration codes (0.312) to raise awareness and encourage adoption of managerial and technological best-practices (0.292) equally across national firms (0.346).

During the period under analysis, as the number of new managerial best-practices increased so did the extent to which the DTI relied on them for supporting national firms' performance. The DTI increasingly (0.253) invested in codification of management knowledge to get hold of knowledge on effectiveness and usefulness of diverse applications of new technologies (i.e. informational guides and collection of case studies), as well as on new management and market strategy concepts (i.e. scoreboards, benchmarking and evaluation tools) (DTI, 1989, 1991, 1995a; 1997a, 1999a, 2000). Connect material, guide to ISO 9000, People skills scoreboard, and BuyIT guidelines are some of the examples of the efforts of DTI on knowledge codification to develop codified devices to be diffused across firms (0.426). These activities were usually executed by technical and professional organisations $(0.598,0.409)$, sometimes with the involvement of the DTI.

Moreover, awareness campaigns, such as 'National Quality campaign', 'Management in the 90s' or 'Fit for the Future', aimed at diffusing information and providing demonstration exercises to firms, included efforts of management knowledge codification to develop informational and guiding tools (0.439). Besides these 'static' investments, the DTI supported the creation of central organisations, as continuous forums for management codification, such as, the Management Charter Initiative, the Investors In People, the British Quality Foundation, in the early 1990s, and in the late 1990s the Council for Excellence in Management and Leadership and the UK Council for Electronic Business. These organisations had as mission to lead knowledge developments in strategic management issues, design new codes of best-practice and promote their diffusion among British firms (DTI, 1989, 1991, 1995a, 2000). 
Results of correlation analysis and T-test for the variable 'Standards and codes to address firms' are reported in Table 2 column 2. Results suggest that the main objective of programmes, using codified packs of knowledge to address firms, was diffusing management best-practice (0.853). Central awareness diffusion campaigns as well as local provision of information, advice and demonstration exercises tended to make use of codified devices. They were of easy and almost free access $(0.449)$ for all firms $(0.413 ; 0.422)$. Most of these programmes relied on previous knowledge codification activities (0.426) and they were implemented by several organisations including experts $(0.317,0.406)$. 'National Quality Campaign', 'Design Campaign', 'Environment best-practice', and 'Partnership with People' are some examples of programmes that relied on codified devices to raise awareness of firms, as well as to encourage and facilitate the adoption of best-practices.

Overall, these results highlight how management knowledge codification allowed updating the message and characteristics of public innovation support to the new management developments, as well as making public support more wide, customisable and immaterial. During the 1980s, most public support focused on the improvement of defined business areas-quality, management systems, marketing and design. It was centrally monitored and consisted mainly of financial subsidies for using consultant advice (The business and technical advisory business services and later the Consultancy Initiative) and of information distribution (the Quality campaign and later the Management in the 90s) (Batchelor and Wood, 1992; DTI, 1986, 1989, 1991). From mid 1990s, innovation support was mostly provided locally by private organisations and consisted mainly of customised delivery of standardised advice and information services as well as of partial public-sponsored specialised services related to diagnostic, benchmarking and best-practices implementation related to human resources, design, business planning, information systems and e-commerce (DTI, 1995a, 1995b, 2000). Hence, during the 1980s and 1990s, many of the DTI innovation supports were provided by using codified management knowledge. Both programmes that included investments in management knowledge codification as well as those that made use of 
codified packs of knowledge to support firms' capabilities development tended not to provide financial subsidies to firms, as shown by the negative and significant correlation coefficient.

\subsection{Summary and discussion}

Our empirical evidence has shown that the outsourcing of policy implementation, as well as efforts to provided more immaterial and updated public innovation support were accompanied by increased investments in knowledge codification. The DTI attempted to codify both its internal knowledge and the knowledge of local policy-providers, managers, consultants and experts. Efforts to codify policy knowledge were channelled through standards setting, calls for new public innovation support services, evaluations of existing public support and benchmarking of policy-providers performance. Efforts to codify management knowledge were mainly addressed by involving technical and professional experts in studies and projects to identify new management developments and best-practices as well as to develop codes, tools, guides to inform, demonstrate and advice firms on how to upgrade their capabilities. Management knowledge codification enabled to increase the national informational basis, as well as to signal the new strategic management issues to both policy-providers and firms.

Additionally, our study has shown that in a context of outsourced policy implementation, codification of central (the DTI) and local (policy-providers, managers and experts) knowledge became crucial to the development of new capabilities and knowledge required to upgrade the quality and design of public business support. This is the consequence of two facts. First, knowledge on how to improve policy implementation and how to customise public support to the needs of firms is increasingly held by policy-providers, while new crucial management knowledge on how to innovate is hold by experts, consultants, and managers. Second, improvement of the design and implementation of public innovation support requires the upgrade of the capabilities of policy-providers. Moreover, as public business support were mainly defined, monitored and implemented by making use of codified 
knowledge, the incremental improvement of its nature, content and form of implementation increasingly required explicit investments in knowledge codification.

Furthermore, our analysis suggests that co-ordination of investments in 'learning-bycodifying' (i.e. learning to codify and to use effectively external codified knowledge to develop new capabilities and knowledge) is crucial for the performance of innovation policies, but as well extremely difficult to be implemented. For example, in the mid 1990s, when preparing to replace the Enterprise Initiative delivered by the DTI regional offices by the Business Links services provided by local private partnerships, the DTI engaged in the codification of knowledge on the most successful innovation supports (i.e. UK Benchmarking index, Connect) (DTI, 1995a,b,c). Moreover, the DTI encouraged policy-providers to comply with wide diffused management standards. Still, few new efforts were put on the codification of the required policy-providers capabilities. Hence, in 1996, an evaluation finds that the quality of public innovation support is not homogeneous, in some cases, even not up to the standard, despite efforts to standardise it partially (Cassel, 1996; Campbell, 1997). In the late 1990s, instead, lack of new investments in codification of characteristics of the best public innovation services and on the required policy-providers capabilities might have provoked stagnation and lack of visibility and homogeneity of public innovation. In particular, the Standard of Professional Competence, which was finally ready in 1999, had been promised for some years (Cassel, 1996; Campbell, 1997, DTI, 2000). Moreover, the restructuring of the standardised/branded public innovation support services only came in 2001, with the development of the Small Business Services brand (DTI, 2000, 2002). Hence, in 1999, the Policy Studies Institute report (2474 firms) and the survey carried out by Strathclyde University for the Federation of Small Businesses (22,000 firms) suggested that overall satisfaction levels among client firms were well below the targets of the DTI (i.e. 80-90\%), and the design of the support service was poor (Bilefsky, 1999; Brown, 1999a,b, 2000). Moreover, heterogeneity of quality and type of innovation support was found across the local 
network of policy-providers, and personal business advice and problem diagnostic were now among the least used services (Brown, 2000; PACEC, 1999). Still, during this period, investments were made in supporting policy-providers to codify their knowledge and in the development and diffusion of new management best-practices to firms.

\section{Conclusions}

The objective of this paper has been to analyse how investments in knowledge codification could be used as innovation policy instruments, while at the same time overcoming the innovation 'inertia trap' caused by reliance on codified knowledge. Analysing the case of the DTI over twenty years, this paper has shown that within a context of outsourced innovation policy implementation, successful update of public support, upgrade of policy-providers capabilities and diffusion of best-practices across national firms require a continuous processes of 'learning-by-codifying'. Through investments in codification of knowledge (held by policy-suppliers, experts and managers), the DTI could collect and use best-practices as sources of learning to improve innovation support. Moreover, to upgrade public innovation support to the new challenges of firms as well as the capabilities of policy-providers, the DTI encouraged its policy-providers to use and produce codified knowledge related to the new firms' needs, new management developments, and the provision of public support. Codification of management knowledge also allowed the DTI to support best-practice diffusion across national firms as well as to lead them to use external sources of learning, including public innovation support services provided by the local policy-providers.

The DTI channelled its efforts to codify policy knowledge through standards setting, procurement for new public innovation support services, evaluations of existing public support and benchmarking of policy-providers efficiency. Investment in codification of management knowledge took mainly the form of procurement of studies or projects involving technical and professional experts into the identification of new management developments 
and best-practices, and into the development of codes, tools and guides to inform and advice firms on how to improve their capabilities. Additionally, through requirement to conform to standards, procurement of new public support services, as well as awareness campaigns, the DTI encouraged the use of these standards by policy-providers and firms. Still, as seen in Section 6.3 , in the 1980s and 1990s, the DTI has not been able to overcome fully the innovation trap of using codified knowledge to address firms and policy-providers, because it partially failed in making timely and balanced investments in codification of knowledge on the characteristics and competences to provide public support.

This paper suggests that positive externalities from 'learning-by-codifying' exist, especially in the context of decentralised and collective processes of knowledge development. To update continuously current public innovation support, governmental departments, which outsource policy execution across a network of private policy-providers, need to rely both on their inhouse learning and on learning and knowledge held by policy-providers and by innovation and management experts. Hence, potentialities for the continuous updating of public business support seem dependent on the technical and codifying capabilities of both policy-providers and the central government department. The performance of central strategies of investing in knowledge codification to assure innovation within a network depends on the capabilities of other players of 'learning-by-codifying', and consequently on the central efforts and incentives put into their development. Moreover, the impact of innovation policies implemented locally by private policy-providers seems to depend on the capabilities of the demand (firms) to be aware of the existing public support, to identify their needs, and to address these policy-providers for business support.

Hence, to overcome the innovation trap of using codified knowledge to address firms and policy-providers, government department needs to create incentives for their employees (policy-makers) as well as policy-providers to codify their knowledge into new services to fit the new policy objectives and to use external codified knowledge as source of learning (i.e. 'learning-by-codifying'). Moreover, central policy-makers need to invest continuously in 
creating incentives as well as to ensure continuity of these investments in central and local 'learning-by-codifying' as well as to give them a direction and an objective. Efforts should also be put on the development of new leading knowledge, as well as on raising awareness of national firms and lead them to look for help and information to adopt best-practices.

Altogether, our analysis suggests that despite outsourcing implementation and part of policy design, central innovation policy-makers have still the very demanding of co-ordinating their own process of learning-by-codifying as well as the one of policy-providers, and to a less extent, of national firm. This is a difficult, but crucial role for the effectiveness of innovation policies. In particular, it is very challenging for central policy-makers to deal with the agency issues, and make policy-providers commit in providing public innovation support and to address as well the less able firms, despite the other business-to-business services they can provide being more profitable.

i Thanks to the availability and collaboration of R. Downing (SBS, DTI), and J. Launchbury (SBS, DTI), who were responsible for the design and implementation of most policies included in the dataset, the content of the database was validated.

ii Moreover, under Export Challenge, the DTI encouraged trade associations to work more closely and effectively to support firms exploiting export opportunities. Under Local Challenges Initiatives and Sector challenges initiatives, the DTI called potential policy-providers to apply for the DTI financing with proposals of new business-to-business services to improve firms' performance (DTI, 1997a, 1997b, 1998). 


\section{References:}

- Andersson, Thomas (1998) Managing a systems approach to Technology and innovation Policy, STI Review 22, 10-28.

- Argote, L. and E. Darr (2000) Repositories of knowledge in franchise organizations: individual, structural and technological, in The Nature and Dynamics of Organizational Capabilities, ed. Dosi G., R. R. Nelson and S. G. Winter, (Oxford: Oxford University Press).

- Batchelor, C. and L. Wood (1992) Ending the fragmentation, Financial Times: 27 Oct.

- Bénézech, D., G. Lambert, B. Lanoux, C. Lerch, J. Loos-Baroin (2001) Completion of knowledge codification: an illustration through the ISO 9000 standards implementation process, Research Policy 30(9), 1395-1407.

- Bessède, C. (2000) La qualité: une démarche pour répondre aux attentes du client, Les 4 pages 138, SESSI, MINEFI, Paris

- Bilefsky, D. (1999) Small companies 'underperform' business government criticised, Financial Times, 23 December.

- British Accreditation Bureau (2004), "Accreditation Schemes", http://www.britishaccreditation.co.uk/bab-references.htm, retrieved October 2004

- Brown, K. (1999a) Inside track: beefing up industry's weak link: Growing businessbusiness links, Financial Times, 26 August.

- Brown, K. (1999b) Small Business Service will be given wide powers, Financial Times, 28 June.

- Brown, K. (2000) Small businesses voice concern over red tape, Survey only 8 per cent happy with Support Services, Financial Times, 20 October.

- Callon, M., P. Laredo and V. Rabeharisoa (1991). Des instruments pour la gestion et l'évaluation des programmes technologiques: le cas de L'AFME. In: L'Évaluation Économique de la recherche et du changement technique, Paris, Editions du CNRS

- Campbell, K. (1997) New vision for Business Links, Financial Times, 7 October.

- Cassell, M. (1996) Heseltine's troublesome baby: The creation of the Business Links network has been welcomed by questions remain over funding and co-ordination, Financial Times, 7 March.

- Chabbal, R. (1995) Characteristics of innovation policies, namely for SMEs, STI Review 16, 103-140.

- Cohen, W. M. and D. A. Levinthal (1990), Absorptive capacity: a new perspective on learning and innovation, Administrative Science Quarterly 35 128-152

- Cohendet, P. (2001). Final Report - Executive Summary TIPIK (Technology and Infrastructures Policy in the Knowledge based Economy - The impact of the tendency towards codification of knowledge), BETA. 
- Cohendet, P. and F. Meyer-Krahmer (2001) The theoretical and policy implications of knowledge codification, Research Policy 30(9), 1563-1591.

- Cohendet, P. and W. E. Steinmueller (2000) The codification of knowledge: a conceptual and empirical exploration, Industrial and Corporate Change 9(2), 195-209.

- Coriat B. and G. Dosi, (2002) The Nature and Accumulation of Organizational Competences/Capabilities, Revista Brasileira de Inovação 1 (1), 275- 326.

- Cowan, R. and D. Foray (1997) The economics of knowledge codification and diffusion, Industrial and Corporate Change 6 (3), 595-622.

- Cowan, R., P. David, and D. Foray (2000) The explicit economics of knowledge codification and tacitness, Industrial and Corporate Change 9 (2), 211-253.

- Dosi, G., R. R. Nelson, S. G. Winter (2000) Introduction: the nature and dynamics of organizational capabilities in The Nature and Dynamics of Organizational Capabilities, ed. Dosi G., R. R. Nelson and S. G. Winter, (Oxford: Oxford University Press)

- Downing, R. C. (2001) Improving design and administration of government support programmes for industry, $\mathrm{PhD}$ thesis, University of Plymouth.

- DTI (1986) The government expenditure plans 1986-87 to 1988-89, Command Paper 9702.

- DTI (1989) The government expenditure plans 1989-90 to 1991-92, Command Paper 605.

- DTI (1991) The government expenditure plans 1991-92 to 1993-94, Command Paper 1504.

- $\quad$ DTI (1995a) Competitiveness: Forging Ahead (CWPII). DTI. Command Paper 2867.

- DTI (1995b) Services for Business. DTI, London

- DTI (1995c). The government expenditure plans 1995-96 to 1997-98, Command Paper 2804.

- DTI (1997a) The government expenditure plans 1997-98 to 1999-2000, Command Paper 3605 .

- DTI (1997b) "Margaret Beckett announces 186 Sector Challenge Winners". DTI Press Release P/97/352; 29 May.

- DTI (1998) The government expenditure plans 1998-99 to 2000-2001, Command Paper 3905 .

- DTI (1999a) The government expenditure plans 1999-2000 to 2001-2002, Command Paper 4211.

- DTI (1999b) Local Support Centres, DTI assessment unit. ISI Evaluation Survey Executive Summary, www.dti.gov.uk/iese/vol3summary.pdf

- DTI (2000) The government expenditure plans 2000-01 to 2001-02, Command Paper 4611. 
- DTI (2002) The government expenditure plans 2002-03 to 2004-05, Command Paper 5416.

- DTI (2004) Support to implement Best practice, http://www.dti.gov.uk/implementbestpractice, retrieved October 2004.

- Edler, J. and L. Georghiou (2007) Public procurement and innovation - Resurrecting the demand side, Research Policy 36, 949-963

- Eisenhardt and Martin (2000) Dynamic Capabilities: What are they?, Strategic Management Journal 21(10/11), 1105-1121

- Foray D. and W. E. Steinmueller (2003) The economics of knowledge reproduction by inscription, Industrial and Corporate Change 12(2), 299-319.

- Institute of Business Advisers (2004) Our History, http://www.iba.org.uk/AboutUs/History/, retrieved October 2004

- Kinder, T. (2002) Good practice in best practice: the use of best practice case studies in service innovation by local public administrations, Science and Public Policy 29 (3),221233

- Kimberly, A. B. and D. G. Hollingworth (2004) The impact of TQM institutionalization on transactions cost calculations in customer-supplier relationships, Industrial and Corporate Change 13(3), 447-503.

- Lipsey, R.G. and K. Carlaw (1997). Technology policies in neo-classical and structuralist-evolutionary models. STI Review 22.

- Marsh, D. and R.A.W. Rhodes (1992). The implementation gap: explaining policy change and continuity, In: Implementing Thatcherite Policies, D. Marsh and R.A.W. Rhodes (Buckingham: Open University Press).

- Metcalfe, J.S. and L. Georghiou (1998) Equilibrium and evolutionary foundations of technology policy, STI Review, 22, 75-100.

- Mytelka, L. K. and K. Smith (2002) Policy learning and innovation theory: an interactive and co-evolving process, Research Policy 31 (8-9), 1467-1479.

- $\quad$ OECD (1993). Public management developments, Survey 1993.

- OECD (2004) Science, Technology and Industry Outlook, OECD

- Paasi, M. (2005) Collective benchmarking of policies: an instrument for policy learning in adaptive research and innovation policy, Science and Public Policy 32(1), 17-27

- PACEC (1999). Business Links Value for Money Study, Public and Corporate Economic Consultants, Business Links Directorate DTI.

- Papaioannou, T., H. Rush and J. Bessant (2006) Benchmarking as a policy-making tool: from the private to the public sector, Science and Public Policy 33 (2),91-102

- Parsons, W., (1995) Public Policy: an introduction to the theory and practice of policy analysis, Aldershot, UK and Brookfield, US: Edward Elgar. 
- Sharp, M. (2000), The UK experiment: science, technology and industrial policy 19751997, Triple Helix Conference, April 2000, Rio de Janeiro, Brazil. 